\title{
Techno-Economic Study on an Energy System in Northwest China
}

\author{
Jie-yuan Yang1,3, Jin-ping Li ${ }^{1,3}{ }^{*}$, Rong Feng² \\ ${ }^{1}$ Energy and Power Engineering Institute, Lanzhou University of Technology, Lanzhou, China \\ ${ }^{2}$ Shanxi University of Technology, Shaanxi Key Laboratory of Industrial Automation, Hanzhong, China \\ ${ }^{3}$ Western China Energy \& Environment Research Center, Lanzhou University of Technology, Lanzhou, China \\ Email: *lijinping77@163.com
}

How to cite this paper: Yang, J.-Y., Li, J.-P. and Feng, R. (2018) Techno-Economic Study on an Energy System in Northwest China. Open Journal of Energy Efficiency, 7, 1-18.

https://doi.org/10.4236/ojee.2018.71001

Received: January 18, 2018

Accepted: March 5, 2018

Published: March 8, 2018

Copyright (c) 2018 by authors and Scientific Research Publishing Inc. This work is licensed under the Creative Commons Attribution International License (CC BY 4.0).

http://creativecommons.org/licenses/by/4.0/

\section{(c) (i) Open Access}

\begin{abstract}
A combined system of heating, power and biogas (CHPB) system has been developed and tested in a single building in MinQin County, Gansu Province, China. The proposed system satisfies the user's demand of power, heat, and gas. The CHPB system can effectively overcome seasonal, climate and many other factors which affect the production of the renewable energy. For this purpose, experiments were conducted extensively during the winter period from November 2014 to March 2015. Compared with conventional energy supply systems meets the test household indoor temperature level, the system can reduce the consumption of standard coal $5819.30 \mathrm{~kg} / \mathrm{year}$, and save energy costs $11,046.20$ yuan/year, the system's payback period of 4.37 years, also can save 27.03 tons of carbon dioxide emissions. As a result, the CHPB system have been successfully tested for single building, use solar energy and biomass as input and produce power, heat, and gas steadily. These results contributed to the construction of energy supply systems.
\end{abstract}

\section{Keywords}

Energy Supply System, Biogas, Solar Heated Digesters, Renewable Energy, Performance Evaluation

\section{Introduction}

PV (photovoltaic) systems are becoming an important part of the electricity system all around the globe, especially in most developed countries. A vigorous growth of the global PV market is still expected due to the strong PV technology price decreases and rise of electricity prices produced by conventional sources together with the clear advantages of green and renewable energy sources as PV 
on delivering safe and clean energy [1].

For the inhabitants of rural China's northwest, the domestic hot water, cooking gas and electricity are the most important energy needs. Currently, China has become the world's largest producer and user of solar water heaters [2]. Shukla et al. [1] pointed out that there are 70 million houses around the world are using the solar hot water system. The solar hot water system's advantage is the environment-friendly aspect, it requires less maintenance and operating costs, when it compared with other solar energy technologies; and Solar hot water system investment payback period is generally $2-4$ years, depending on the form and size of the system. Rahma et al. [3] pointed out that the use of livestock and poultry in rural areas to produce biogas and solar energy to meet the thermal and electrical needs of the integrated system has not been deserved and attention. The study found that in Bangladesh, each household when raises three to six cows they could meet their cooking and electricity needs by integrating biogas and solar photovoltaic power generation. Nakata et al. [4] analyzed the prospects of using renewable energy for energy supply in some areas of Japan. The results of the study show that the use of wind energy and ground source heat pump has good prospects. Dagougun et al. [5] have integrated flat-panel solar collectors, biomass power plants, wind turbines, and PV modules to provide heat and power for a green building. Gaul et al. [6] conducted a comparative study on the use of Jatropha oil, biogas and other small-scale rural energy services based on a full life-cycle analysis model, focusing on the reliability and feasibility of energy demand for radiationing, cooking and mechanical energy, while the production and processing costs of Jatropha oil have a great impact on the optimization program. Helal et al. [7] discussed the use of renewable energy in a sewage treatment station to meet their own energy needs of the program. Jenssen et al. [8] describe the use of biomass in an eco-village in Germany to provide users with thermal energy and electricity. Gonzalez et al. [9] presented a scheme for the use of biogas and solar photovoltaic in pig slaughterhouses to solve their own energy and environmental problems, the results show that the optimal choice is to build anaerobic digesters with a capacity of $79 \mathrm{kWh}$ and a $225 \mathrm{kWh}$ photovoltaic power generation system with an investment payback period of 9 years.

Hosseinalizadeh et al. [10] compared the technical and economic characteristics of wind, PV, fuel cell and accumulator systems in different ways, based on solar radiation and average wind speed data from four typical regions in Iran. It was found that wind power, photovoltaic and battery combination system costs were lower. Fuel cells, due to high cost, short life, are not suitable for integrated systems. Chauhn and Saini [11] used HOMER software to analyze and contrast the use of renewable energy technologies that integrate micro hydropower, biogas, biomass, solar, wind and accumulators in different ways. In the rural areas of Gemaly, North Arkadia, India, to meet the local technical and economic needs for electricity and cooking. 
The vigorous growth of renewable energy in rural areas leads to huge development of rural economy and the protection of the environment, which is of great significance, further it related to the national energy security issues. However, the current irrational energy structure, energy supply and energy use methods are relatively backward problems are still widespread in China's vast rural areas [12] [13]. In most of China's rural areas, especially in the northwest areas the demand for heat it is still achieved through the direct combustion of firewood, coal, plant stalks and other means. The use of energy in this way it caused a great waste of natural resources, increase the environmental impact in rural areas, destruction of natural resources, and caused serious harm to the health of farmers [14].

The solar water heaters are used to control the temperature required for biogas fermentation. Solar thermal, solar photovoltaic, anaerobic fermentation biogas system, three subsystem are ultimately realize the benefits of heat, power, and gas [15], while meet the farmers demand for heating and electricity in winter. In this paper, the cooperative coupling law influenced by many factors on the system performance is conducted. The system economic, environmental and social benefits are analyzed.

\section{Design System}

There are two groups of solar hot water, group I provide a nearly unwavering temperature condition to thermostatic pool for anaerobic fermentation, the biogas produced by the thermostat digesters is stored in the storage bag and partly used as cooking gas, and group II cooperatively provide heating and domestic hot water. Photovoltaic battery power used to drive the circulating water pump for conveying hot water in vacuum tube solar water heater group to thermostatic pool for anaerobic fermentation the other part is used to drive the heating hot water, and the rest is used for living electricity. The working principle of the system as shown in the Figure 1.

\section{Passive Houses and Calculated Energy Demand}

\subsection{Solar Constant Temperature Digesters and Vacuum Tube Solar Energy}

According to "GB50495-2009 solar heating engineering technical specifications" [16] [17] and "JGJ26-2010 cold and cold areas of residential building energy efficiency design standards" [18] Computing architecture material consumptions of heat.

The ecological farmhouse for the north and south, brick and concrete structure, the external dimensions of the building are $12.02 \mathrm{~m} \times 9.74 \mathrm{~m} \times 3.30 \mathrm{~m}$ and the area is $117.07 \mathrm{~m}^{2}$; the internal structure of the building is divided into three bedrooms, a living room, a kitchen, a bathroom and a hall. The northeast corner bedroom size is $3.00 \mathrm{~m} \times 3.36 \mathrm{~m}$, the area is $10.08 \mathrm{~m}^{2}$, southwest corner bedroom size $3.00 \mathrm{~m} \times 3.60 \mathrm{~m}$, and the area is $10.80 \mathrm{~m}^{2}$; southeast corner of the kitchen size 


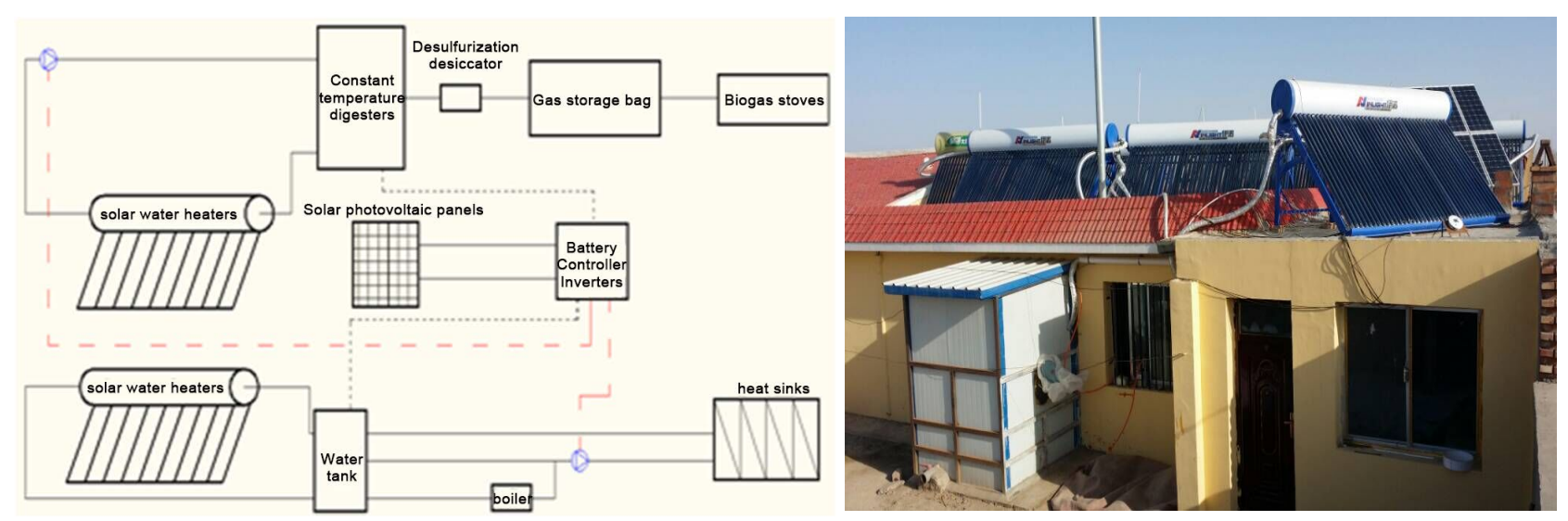

Figure 1. Working principle of the system and arrangement.

is $3.00 \mathrm{~m} \times 3.60 \mathrm{~m}$, and the area is $10.80 \mathrm{~m}^{2}$; living room size is $3.00 \mathrm{~m} \times 3.30 \mathrm{~m}$, and the area is $9.90 \mathrm{~m}^{2} ; 4.80 \mathrm{~m} \times 3.60 \mathrm{~m}$, and the area is $17.28 \mathrm{~m}^{2}$; bathroom size of $1.56 \mathrm{~m} \times 2.11 \mathrm{~m}$, and the area is $3.29 \mathrm{~m}^{2}$; hall size of $3.23 \mathrm{~m} \times 4.54 \mathrm{~m}$, and the area is $14.67 \mathrm{~m}^{2}$.

The north-east corner of the building bedroom and northwest corner of the north wall bedroom has a window in the middle of the southwest corner bedroom, living room walls have a window on the south wall, windows are three glass windows (double insulating glass plus single-layer ordinary glass), the kitchen windows are double glazed windows with dimensions of $1.70 \mathrm{~m} \times 1.43$ $\mathrm{m}$, the living room and the entrance hall of the partition wall on both sides of a window, the window is a single glass windows, the size of $1.02 \mathrm{~m} \times 1.43 \mathrm{~m}$, the door outside the left and right sides of a window, windows for the single glass windows; three bedrooms, kitchen and bathroom door height are $2.04 \mathrm{~m}$, in addition to the bathroom door for the glass door, the three bedroom and kitchen doors are wooden doors, aluminum doors for the living room door glass doors, a height of $2.31 \mathrm{~m}$, the door is a common security doors, a height of $2.75 \mathrm{~m}$. Indoor radiator for the aluminum composite radiator, north-east corner bedroom and northwest corner of the bedroom north wall of a group of radiator, southwest corner bedroom south wall of a group of radiator, living room south wall has two sets of radiator, a single radiator size of $2.30 \mathrm{~m} \times 0.08 \mathrm{~m} \times 0.63 \mathrm{~m}$, bathroom west wall has a group of radiators, the size of $0.80 \mathrm{~m} \times 0.08 \mathrm{~m} \times 0.63 \mathrm{~m}$. An architectural diagram of the house is shown in Figure 2.

\subsubsection{The Establishment of Heating System}

1) According to "solar heating engineering technical specifications" and "cold areas of residential building energy efficiency design standards" to calculate the building total heat consumption as shown in Equation (1).

$$
Q_{H}=Q_{w h}+Q_{l f s}+Q_{l f q}
$$

$Q_{H}$ is the total heat consumption of buildings (W); $Q_{w h}$ is the basic heat consumption retaining structure (W); $Q_{l f s}$ is cold air penetration heat consumption (W); $Q_{\text {Ifq }}$ is cold air intrusion heat consumption (W). 


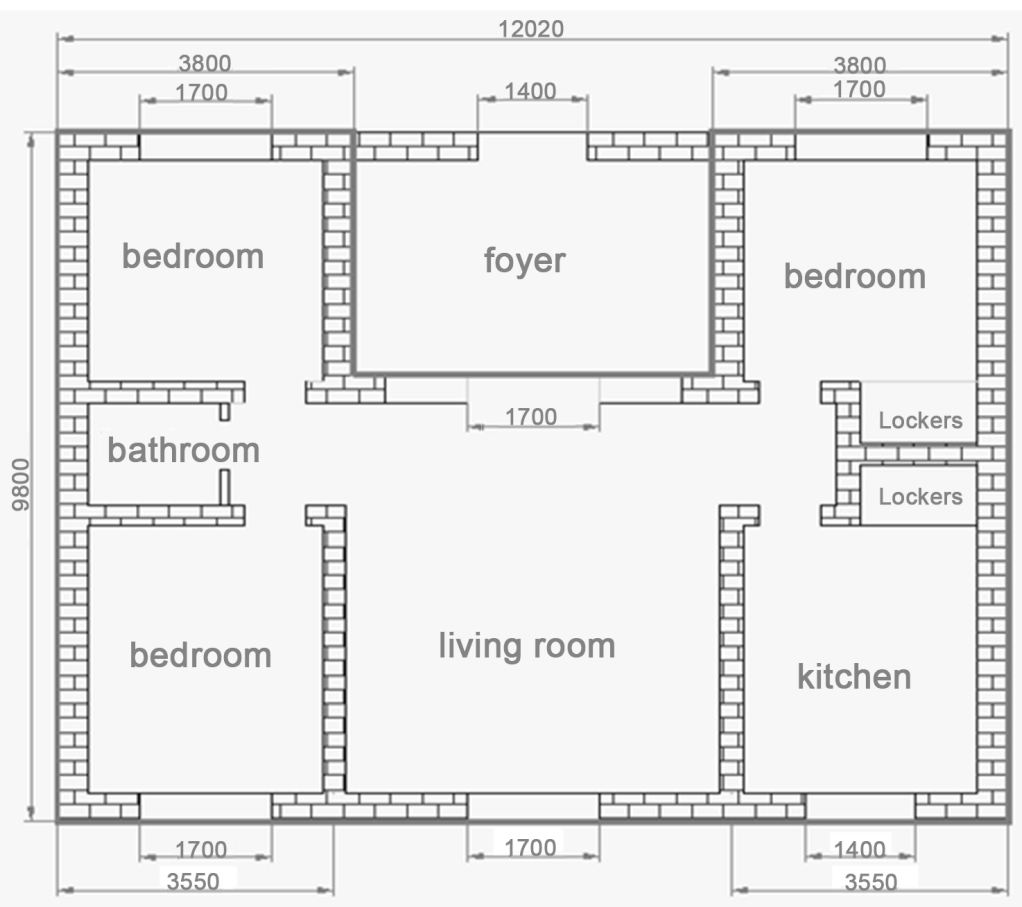

Figure 2. Experiment residents floor plan.

The $Q_{w h}$ stands for the basic heat consumption by retaining structure as shown in Equation (2), (3) and (4):

$$
\begin{gathered}
Q_{w h}=\sum Q_{i}^{\prime} \\
Q_{i}^{\prime}=Q_{i} \cdot \varepsilon \\
Q_{i}=\left(t_{i}-t_{e}\right) K_{i} F_{i}
\end{gathered}
$$

$Q_{i}^{\prime}$ is revised the basic heat transfer of the structure(W); $Q_{i}$ is basic heat transfer of the enclosure structure (W); $\varepsilon$ is total correction (the total correction rate, the risk attaching rate and the height addition rate); $t_{i}$ is the indoor air calculates the temperature $\left({ }^{\circ} \mathrm{C}\right) ; t_{\mathrm{e}}[19]$ is the calculation of outdoor heating temperature $\left({ }^{\circ} \mathrm{C}\right), K_{i}$ is the heat transfer coefficient of each envelope $\left(\mathrm{W} /\left(\mathrm{m}^{2} \cdot \mathrm{K}\right)\right), F_{i}$ is the area of the envelope $\left(\mathrm{m}^{2}\right)$.

Calculated, the detail of the building envelope is presented in Table 1, heat transfer heat consumption for retaining structure is $Q_{w h}=4314.66 \mathrm{~W}$.

Cold air penetration heat consumption $Q_{\text {lfs }}$ [19] [20] as shown in Equation (5):

$$
Q_{\text {lfs }}=0.278 V N C_{P} \rho\left(t_{i}-t_{e}\right)
$$

$V$ is the interior volume of the room $\left(\mathrm{m}^{3}\right) ; N[20]$ is the number of ventilation (times $/ \mathrm{h}) ; c_{p}$ is cold air constant pressure specific heat capacity $\left(\mathrm{kJ} /\left(\mathrm{kg} \cdot{ }^{\circ} \mathrm{C}\right)\right) ; \rho$ is air density.

Calculated, cold air penetration heat consumption is $Q_{\text {Ifs }}=1581.64 \mathrm{~W}$;

Cold air intrusion heat consumption $Q_{\text {Ifq }}$ as shown in Equation (6):

$$
Q_{\text {Ifq }}=0.65 Q_{\text {door }}
$$

Calculated, cold air intrusion heat consumption is $Q_{I f q}=129.82 \mathrm{~W}$ 
Table 1. Shows the detail of the building envelope.

\begin{tabular}{|c|c|c|c|c|}
\hline $\begin{array}{l}\text { Building } \\
\text { envelope }\end{array}$ & Structure & $\begin{array}{c}\text { Heat transfer } \\
\text { coefficient } K_{i} \\
{\left[\mathrm{~W} /\left(\mathrm{m}^{2} \cdot \mathrm{K}\right)\right]}\end{array}$ & $\begin{array}{l}\text { Heat transfer } \\
\text { area } F_{i}\left[\mathrm{~m}^{2}\right]\end{array}$ & $\begin{array}{l}\text { Correction } \\
\text { coefficient } \varepsilon_{i}\end{array}$ \\
\hline Roof & $\begin{array}{l}\text { From top to bottom: decorative surface } \\
\text { layer for } 50 \mathrm{~mm} \text {, stone concrete cover } \\
\text { for } 40 \mathrm{~mm} \text {, waterproof layer for } 400 \mathrm{~mm} \text {, } \\
\text { slope layer for } 20 \mathrm{~mm} \text {, polystyrene board } \\
\text { insulation layer for } 80 \mathrm{~mm} \text {, cement } \\
\text { mortar for 1:3, reinforced concrete for } \\
\text { roof slab }\end{array}$ & 0.394 & 117.07 & 0.94 \\
\hline $\begin{array}{c}\text { Exterior } \\
\text { wall }\end{array}$ & $\begin{array}{l}\text { From the inside out: mixed mortar for } \\
20 \mathrm{~mm} \text {, solid brick for } 240 \mathrm{~mm} \text {, adhesive } \\
\text { and cement mortar leveling layer for } 30 \\
\mathrm{~mm} \text {, polystyrene board insulation layer } \\
\text { for } 80 \mathrm{~mm} \text {, anti-crack mortar and } \\
\text { alkali-resistant fiberglass mesh for } 5 \mathrm{~mm} \text {, } \\
\text { decorative surface layer for } 15 \mathrm{~mm}\end{array}$ & 0.393 & $\begin{array}{c}\text { North } 22.56 \\
\text { East } 26.17 \\
\text { West } 26.17\end{array}$ & $\begin{array}{l}\text { North } 0.95 \\
\text { East } 0.91 \\
\text { West } 0.90\end{array}$ \\
\hline Window & $\begin{array}{l}\text { Double glazed windows, glass thickness } \\
4 \mathrm{~mm} \text {, air layer thickness } 12 \mathrm{~mm}\end{array}$ & 2.92 & $\begin{array}{c}\text { South } 2 \\
\text { windows: } 2.43 \\
\text { Nouth } 2 \\
\text { windows: } 2.43\end{array}$ & $\begin{array}{l}\text { South } 0.43 \\
\text { North } 0.75\end{array}$ \\
\hline Door & & 2 & $\begin{array}{c}\text { Double open } \\
\text { security doors } \\
4.68\end{array}$ & 1.1 \\
\hline Ground & $\begin{array}{l}\text { concrete base for } 100 \mathrm{~mm} \text {, cement } \\
\text { mortar leveling layer for } 20 \mathrm{~mm} \text {, } \\
\text { reflective layer of aluminum foil } \\
\text { anti-radiation layer for } 0.05 \mathrm{~mm} \text {, } \\
\text { extrusion polystyrene board insulation } \\
\text { for } 60 \mathrm{~mm} \text {, concrete filling for } 50 \mathrm{~mm} \text {, } \\
\text { cement mortar leveling layer for } 20 \mathrm{~mm} \text {, } \\
\text { floor tile ground floor for } 8 \mathrm{~mm}\end{array}$ & 0.35 & 117.07 & 1 \\
\hline
\end{tabular}

Consequently, building total heat consumption

$Q_{H}=Q_{w h}+Q_{l f s}+Q_{l f q}=6026.12 \mathrm{~W}$. Per square meter heat consumption is 51.47 $\mathrm{W} / \mathrm{m}^{2}$.

2) According to "GB50495-2009 solar heating engineering technical specifications" [16] [17] calculate the daily average heat consumption of domestic hot water as shown in Equation (7).

$$
Q_{w}=\frac{m_{w} q_{r} c_{w} \rho_{w}\left(t_{r}-t_{f}\right)}{86400}
$$

$Q_{W}$ is average heat consumption of domestic hot water (W); mw is the number of water users (people); $q_{r}[17]$ the quota of hot water; (L/(person.d)); $c_{w}$ is specific heat capacity of water $\left(\mathrm{J} /\left(\mathrm{kg} .{ }^{\circ} \mathrm{C}\right)\right) ; \rho_{w}$ is hot water $\operatorname{density}(\mathrm{kg} / \mathrm{L}) ; t_{r}$ is design the hot water temperature $\left({ }^{\circ} \mathrm{C}\right) ; t_{f}$ is design the cold water temperature $\left({ }^{\circ} \mathrm{C}\right)$.

Calculated, average heat consumption of domestic hot water is $Q_{W}=24.70 \mathrm{MJ} / \mathrm{d}$.

3) Calculation of heat consumption of digester

(1) The amount of heat required to heat the feedstock [18] [19] [20] [21] as 
shown in Equation (8)

$$
Q_{1}=c_{L} m_{L}\left(T_{D}-T_{S}\right)
$$

$Q_{1}[21]$ is the amount of heat required to heat the feedstock $(\mathrm{W}) ; c_{L}$ is specific heat capacity of liquid $\left(\mathrm{kJ} /\left(\mathrm{kg} \cdot{ }^{\circ} \mathrm{C}\right)\right) ; m_{L}[19]$ is the daily volume of fresh feed into the digester(kg/day); $T_{D}$ is temperature of liquid in biogas fermentation $\left({ }^{\circ} \mathrm{C}\right) ; T_{\mathrm{S}}$ [22] is the temperature of the fresh feed $\left({ }^{\circ} \mathrm{C}\right)$.

Calculated, $Q_{1}=2.91 \mathrm{MJ} / \mathrm{d}$.

(2) Heat loss of heat transfer pipeline of biogas digester [23] as shown in Equation (9)

$$
Q_{2}=2 \pi \cdot \frac{T_{D}-T_{A}}{\frac{1}{\lambda_{1}} \ln \frac{d_{o}}{d_{i}}+\frac{1}{\lambda_{2}} \ln \frac{4 a}{d_{o}}} \cdot L \cdot(1+\beta)
$$

$Q_{2}$ is heat loss of biogas digesters' heat transfer pipelines (W); $T_{A}$ is the temperature of the media outside the $\operatorname{tank}\left({ }^{\circ} \mathrm{C}\right) ; \lambda_{1}$ is the coefficient of the polystyrene's thermal conductivity $\left(\mathrm{W} /\left(\mathrm{m}^{2} \cdot \mathrm{K}\right)\right) ; \lambda_{2}$ is the coefficient of the soil's thermal conductivity $\left(\mathrm{W} /\left(\mathrm{m}^{2} \cdot \mathrm{K}\right)\right) ; d_{0}$ is the outer diameter of the heat transfer pipe $(\mathrm{m}) ; d_{i}$ is the internal diameter of the heat transfer pipe $(\mathrm{m})$; a is buried depth $(\mathrm{m}) ; L$ is the length of the root pipe $(\mathrm{m}) ; \beta$ is local heat loss coefficient.

Calculated, $Q_{2}=56.41 \mathrm{MJ} / \mathrm{d}$.

(3) Heat consumption of biogas digester's exterior-protected construction as shown in Equation (10)

$$
Q_{3}=F \cdot \frac{1}{\frac{1}{h_{1}}+\frac{\delta_{3}}{\lambda_{3}}+\frac{\delta_{4}}{\lambda_{4}}+\frac{1}{h_{2}}} \cdot\left(T_{D}-T_{A}\right)
$$

$Q_{3}$ is heat consumption of biogas digester's exterior-protected construc$\operatorname{tion}(\mathrm{W}) ; F$ is the external surface area of biogas digesters $\left(\mathrm{m}^{2}\right) ; h_{1}$ is internal convection heat transfer coefficient of digesters $\left(\mathrm{W} /\left(\mathrm{m}^{2} \cdot \mathrm{K}\right)\right) ; \delta_{3}$ is the thickness of concrete slab $(\mathrm{m}) ; \delta_{4}$ is the thickness of biogas insulation layer $(\mathrm{m}) ; \lambda_{3}$ is thermal conductivity of concrete slab $(\mathrm{W} /(\mathrm{m} \cdot \mathrm{K})) ; \lambda_{4}$ is thermal conductivity of polystyrene board $(\mathrm{W} /(\mathrm{m} \cdot \mathrm{K})) ; h_{2}$ is heat transfer coefficient between the outer surface of insulation layer and environment $\left(\mathrm{W} /\left(\mathrm{m}^{2} \cdot \mathrm{K}\right)\right)$.

Calculated, $Q_{3}=17.24 \mathrm{MJ} / \mathrm{d}$

(4) Anaerobic reactions produce biological heat

When anaerobic fermentation reaction, $3 \%$ of the effective energy of the fermentation liquid is released in the form of heat, which is the heat generated by the reaction when the Human and livestock manure converted to methane [24]. The heat produced during fermentation is $Q_{4}(\mathrm{~W}), Q_{4}=0.0195 \mathrm{MJ} / \mathrm{d}$.

The total heat requirement of biogas digesters is $Q_{m}(\mathrm{~W})$, $Q_{m}=Q_{1}+Q_{2}+Q_{3}-Q_{4}=76.56 \mathrm{MJ} / \mathrm{d}$.

From the above calculation, the building energy output is $Q_{0}(\mathrm{~W})$, $Q_{0}=Q_{H}+Q_{W}+Q_{m}=621.92 \mathrm{MJ} / \mathrm{d}$. 


\subsubsection{The Establishment of Power Generation System}

Total electricity consumption equal to Electricity for digester circulating pump [24] [25] plus Heating cycle pump power [26] [27].

The system power requirements are provided by the amount of electricity generated by the solar PV modules.

\subsection{System Performance Analysis}

\subsubsection{Performance Analysis of Solar Photovoltaic Module}

The experiment was conducted in Minqin County, Gansu Province, China. Specific geographical position is in the longitude between $101^{\circ} 49^{\prime} 41^{\prime \prime}-104^{\circ} 12^{\prime} 10^{\prime \prime}$, latitude between $38^{\circ} 3^{\prime} 45^{\prime \prime}$ - 39 $27^{\prime} 37^{\prime \prime} .206 \mathrm{~km}$ long from east to west, north-south width of $156 \mathrm{~km}$, with a total area of 15,900 square kilometers. The county's lowest elevation of 1298 meters, the highest elevation of 1936 meters, with an average elevation of 1400 meters, there is composed of the desert, low hills and plains three topography composition. The user home throughout the winter heating period for experimenting, a total of 101 days of experiment time, the total power generation $260.7 \mathrm{kWh}$, photoelectric conversion efficiency of $8.2 \%$, the average daily generating capacity of $2.6 \mathrm{kWh}$, the system itself, the cumulative power consumption of $127.3 \mathrm{kWh}$. Thus it can be seen, during the experiment period, the surplus power generation was $133.4 \mathrm{kWh}$, which fully met the users' energy demand.

Figure 3(a) is February 4, 2015 power consumption during the experiment reached a maximum, up to $3.6 \mathrm{kWh}$, and the day's power generation was 3.2 $\mathrm{kWh}$, failed to meet user demands for electricity, mainly due to the same day the solar thermostat anaerobic fermentation system using auxiliary heating device, the use of electricity far more than the average power consumption of the system.

average power generation efficiency $=\frac{P V \text { array power generation }}{\text { the solar energy projected onto the } P V \text { array }}$

$$
=\frac{\sum U I t}{\sum I_{\theta} t A}=\frac{\sum U I}{\sum I_{\theta} A}
$$

Figure $3(\mathrm{~b})$ is a graph showing the power generation efficiency of the photovoltaic cell of the unitary thermoelectric gas supply system, the figure shows the most of the efficiency of photovoltaic power generation concentrated between $8 \%$ to $12 \%$, Some factors affects the efficiency of photovoltaic power generation are:

1) Natural environmental factors: solar radiation intensity

Irradiation intensity is the decisive factor affecting the power of PV arrays. The reasonable estimation of solar radiation is very important for the design and research of photovoltaic power generation system. The solar radiation to the unit area of radiation power called radiosity or irradiance, unit for $\mathrm{W} / \mathrm{m}^{2}$, the amount of solar energy projected onto a unit area over a period of time (Day, month, and year) is called the amount of radiation. 


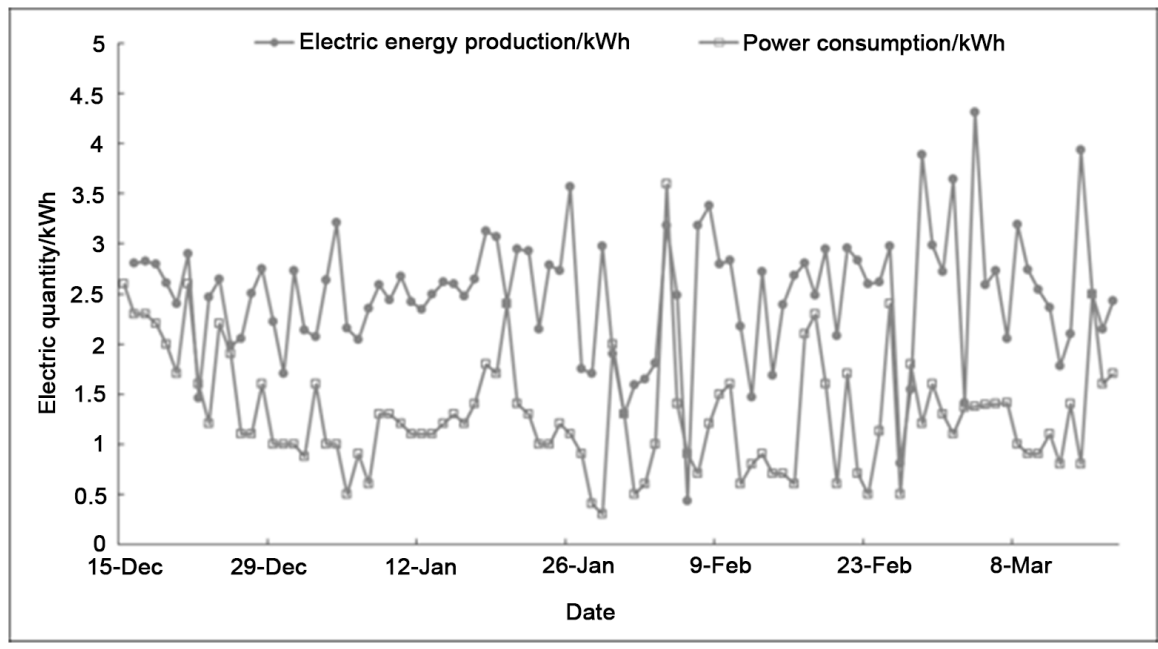

(a)

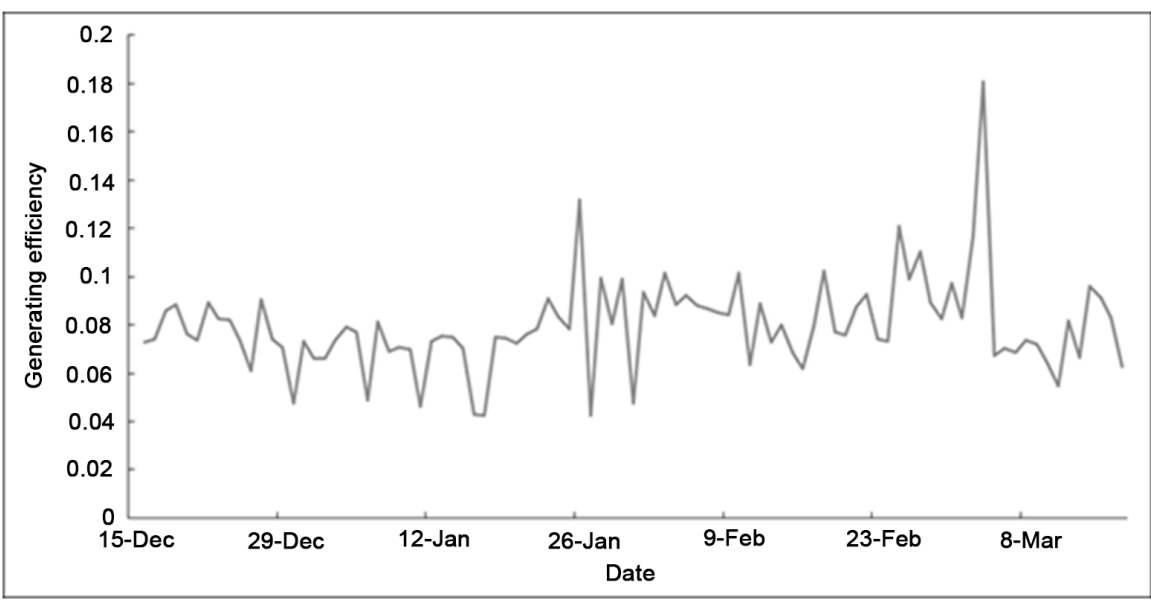

(b)

Figure 3. (a) Electric energy production and power consumption; (b) Photovoltaic power generation efficiency.

When the radiation intensity changes, the PV array short-circuit current, maximum power and other parameters will change. Short-circuit current affected by radiation intensity, radiation weakened, and the output current decreases. While the output voltage is affected by the radiation intensity is relatively small. Figure 4 shows the variation of solar irradiance over one day, March 3, 2015. From 08:16 at morning, the solar irradiance rises to $120 \mathrm{~W} / \mathrm{m}^{2}$ and gradually increases, at 13:02 increase to the peak of $1017.8 \mathrm{~W} / \mathrm{m}^{2}$, after that the solar irradiance began to decline, $18: 01$ down to $120 \mathrm{~W} / \mathrm{m}^{2}$. And hence the amount of solar radiation is $158.5 \mathrm{MJ}$, photovoltaic power generation system 3.7 $\mathrm{kWh}$, which is much higher than the system power consumption.

Figure 4 can also be seen in the morning 7:30 PV power generation system began to produce electricity, then the user get up start to use the electricity, but this time there is little power, the user can use the electricity stored in the battery. As the solar irradiance increases, more and more electric energy is generated. In this way, the small amount of electric energy accumulated in the battery 


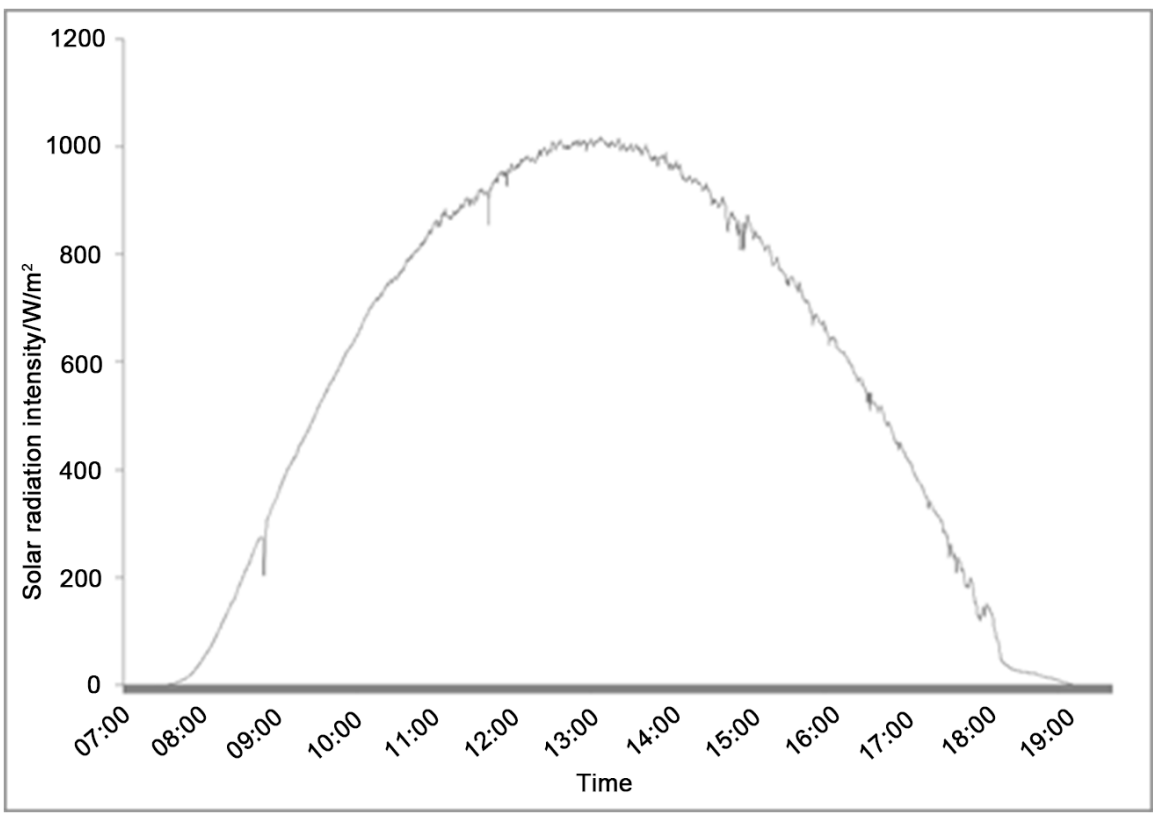

Figure 4. Solar irradiance change trend chart on March 3, 2015.

can make the photovoltaic unit of the combined thermal and electric system can provide the users with uninterrupted electric energy, to meet the user's energy needs.

2) PV modules

(1) Conversion efficiency of PV modules

The power generation efficiency of PV systems is closely related to the performance of PV components. Characterization of photovoltaic components performance parameters are open circuit voltage, short circuit current, and maximum operating point current, Therefore, in order to improve the intensity of the radiation received by $\mathrm{PV}$ modules, some institutions focus on the development and integration of high-power PV power generation technology [28] [29] [30].

The system aim to a lower the cost, reduce the area and to ensure that users suffer uninterrupted supply of electricity demand, as far as possible. To improve the efficiency of photovoltaic power generation, select 10 monocrystalline silicon photovoltaic panels, size $1200 \mathrm{~mm}{ }^{\star} 537 \mathrm{~mm} * 35 \mathrm{~mm}$, with a power $100 \mathrm{Wp}$, so a result the component conversion efficiency is relatively high, without a greater impact.

(2) Shadows shade, the PV module is out of alignment

The system uses ten photovoltaic panels, each two photoelectric cells connected in series to form one group, and by coupling five groups together the designated output is achieved.

Many factors affect the performance of the PV system in actual operation such as: accumulation of dust, excretion of birds, leaves, snow and other just to mansion a few of them. The parameters of each photovoltaic module in the PV array are different from each other. These factors often cause the PV array to be mismatched and the overall power of the array will be lower than the expected value. 
Figure 5 shows the evolution of the voltage and current changes from 8:00 to 18:00, the voltage began to rise at 8:00 at morning, reaching the peak at 14:00, after which began to slowly decline. The current start to build up at 8:00 to rise rapidly, at 11:00 began to decline rapidly, than the voltage peak time 3 hours earlier, just after 11:00 in the morning after the rapid start the change is reduced to zero. This is mainly because the solar photovoltaic panels placed in the user's home, subject to roof topography constraints. As Figure 5 shown, the solar elevation angle changes, the lower left corner of the photovoltaic panels are blocked partially from of the solar radiation, so each PV module parameters cannot be completely consistent. The larger the occlusion area, the smaller the current produced, and the rapid change of current leads to the mismatching operation of the array, which leads to the decrease of the daily output power. This is the main reason for the low efficiency of the PV power generation system.

(3) Inverters

The magnitude of the DC power input to the inverter is determined from the current-voltage curve of the PV array, at the maximum peak of the solar PV array power. According to different parameters, voltage, current and capacitance, etc., there are many methods of operation adapted to inverters of the maximum power peak tracking. But each method has some limitations; making the maximum power inverter tracking less than the required efficiency.

Based on the experimental data, the multivariate regression equation method was adopted; analyze the influence of ambient temperature, daily average heat collection and solar power generation efficiency on daily generation as shown in Table 2.

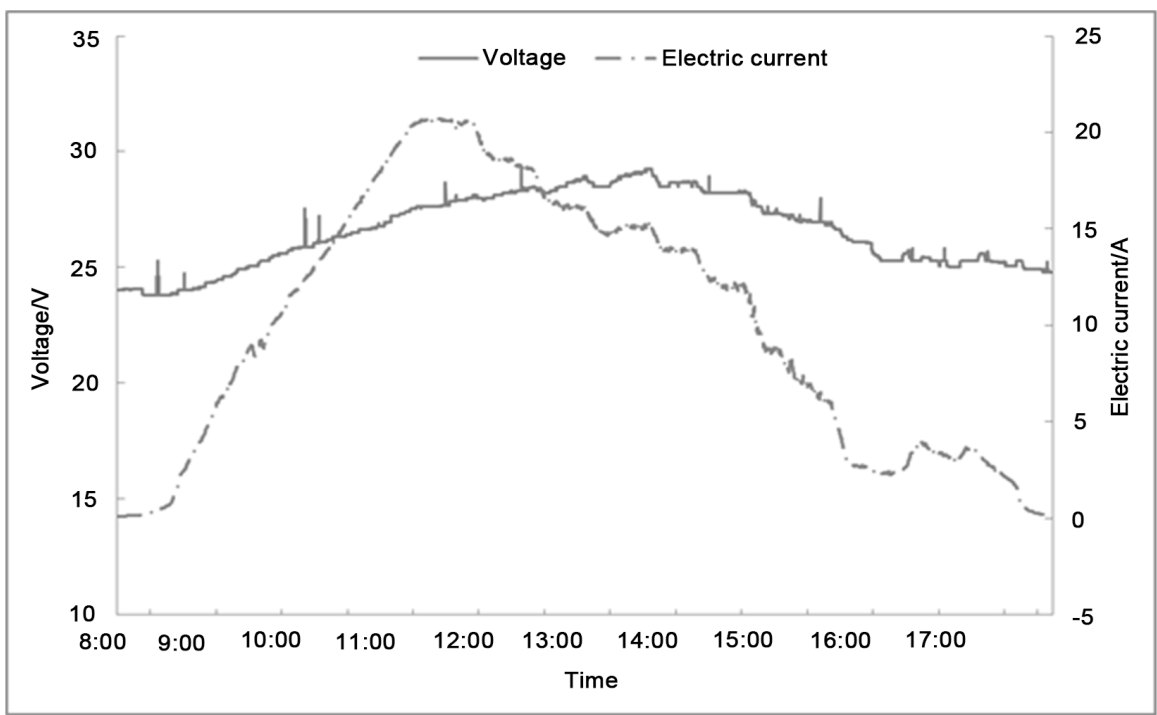

Figure 5. Voltage and current trend chart.

Table 2. Experimental data processing results.

\begin{tabular}{cccccc}
\hline R Square & Standard deviation & Significance $F$ & $\eta$ & $Q_{\text {s-d }}$ & $T$ \\
\hline 0.889 & 0.213 & $2.211 \mathrm{E}-42$ & 29.602 & 0.021 & 0.002 \\
\hline
\end{tabular}


The relationship between relative power generation efficiency, ambient temperature and daily average heat accumulation:

$$
Y=-2.305+29.602 \eta+0.021 Q_{s-d}+0.002 T
$$

where in, $\eta$-power generation efficiency;

$Q_{s-d}$-daily average heat accumulation, MJ;

$T$-ambient temperature, ${ }^{\circ} \mathrm{C}$.

From the table, Significance $\mathrm{F}<0.05$, indicating that the linear model of relative power generation efficiency, ambient temperature and daily average heat collection is significant. The results from the formula (11) can be explained in the factors affecting power generation, of which $88.9 \%$ by the ambient temperature, power generation efficiency and daily average heat between the linear relationship to explain, indicating a higher degree of regression of the regression equation. The prediction error is 0.213 .

Partial regression coefficient $\eta=29.602$, the daily average heat and ambient temperature conditions are maintained unchanged, the power generation efficiency for each additional $1 \%$ relative to the average daily power generation increased $0.296 \mathrm{kWh}$; partial regression coefficient $Q_{s-d}=0.021$, the power generation efficiency and ambient temperature conditions are maintained unchanged, the daily average heat for each additional $1 \mathrm{MJ}$, relative to the daily average increase of power generation $0.021 \mathrm{kWh}$; partial regression coefficient $\mathrm{T}=0.002$ that the power generation efficiency and daily average heat collection conditions are maintained unchanged, the ambient temperature for each additional $1^{\circ} \mathrm{C}$, relative to the average daily power generation increased by $0.002 \mathrm{kWh}$.

\subsubsection{Performance Analysis of Solar Constant Temperature Biogas Digesters}

The main factors influencing the anaerobic fermentation process of solar constant temperature biogas digesters are solar hot water temperature, digester temperature, ambient temperature, etc. According to the experimental data analysis found that the solar hot water temperature, biogas digesters temperature and ambient temperature on the biogas production gas coupling effects as shown in Table 3:

$$
Y=1.032+0.055 T_{1}+0.163 T_{2}+0.071 T_{3}
$$

where in, $T_{1}$ - solar hot water temperature, ${ }^{\circ} \mathrm{C}$;

$\mathrm{T}_{2}$ - temperature of biogas digesters, ${ }^{\circ} \mathrm{C}$;

$T_{3}$-ambient temperature, ${ }^{\circ} \mathrm{C}$.

Table 3 shows Significance F $<0.05$, indicating that the linear model of solar hot water temperature, ambient temperature and temperature of biogas digesters is significant. The results from the formula (12) can be explained in the factors

Table 3. Experimental data processing results.

\begin{tabular}{cccccc}
\hline R Square & Standard deviation & Significance $F$ & $T_{1}$ & $T_{2}$ & $T_{3}$ \\
\hline 0.938 & 0.025 & 0.015 & 0.055 & 0.163 & 0.071 \\
\hline
\end{tabular}


affecting biogas production, of which $93.8 \%$ by the solar hot water temperature, ambient temperature and temperature of biogas digesters between the linear relationship to explain, indicating a higher degree of regression of the regression equation. The prediction error is only 0.025 .

Partial regression coefficient $T_{1}=0.055$, said in the temperature of biogas digesters and ambient temperature are maintained unchanged conditions, the solar hot water temperature for each additional $1^{\circ} \mathrm{C}$ relative to the average biogas production increased $0.055 \mathrm{~m}^{3}$; partial regression coefficient $T_{2}=0.163$, said in the solar hot water temperature and ambient temperature are maintained unchanged conditions, the temperature of biogas digesters for each additional $1^{\circ} \mathrm{C}$, relative to the average biogas production increased $0.163 \mathrm{~m}^{3}$; partial regression coefficient $T_{3}=0.071$ that the solar hot water temperature and temperature of biogas digesters are maintained unchanged conditions, the ambient temperature for each additional $1^{\circ} \mathrm{C}$, relative to the average biogas production increased $0.071 \mathrm{~m}^{3}$.

\subsubsection{Analysis of Solar Heating Performance}

During the winter heating experiment, the maximum outdoor ambient temperature is $32.36^{\circ} \mathrm{C}$ and the lowest is $-18.16^{\circ} \mathrm{C}$.

The main factors influencing daily average heat collection efficiency are daily average heat accumulation and ambient temperature, etc. According to the experimental data analysis found that the daily average heat accumulation and ambient temperature on the daily average heat collection efficiency as shown in Table 4:

$$
y=0.962+0.007 T_{3}+0.003 Q_{s-d}
$$

where in, $Q_{s-d}-$ daily average heat accumulation, $\mathrm{MJ}$;

$T_{3}$-ambient temperature, ${ }^{\circ} \mathrm{C}$.

From the analysis of variance table can be seen, Significance F $<0.05$, indicating that the linear model of daily average heat accumulation and ambient temperature is significant. The results from the formula can be explained in the factors affecting daily average heat collection efficiency, of which $95.7 \%$ by the daily average heat accumulation and ambient temperature between the linear relationship to explain, indicating a higher degree of regression of the regression equation. The prediction error is only 0.024 .

Partial regression coefficient $Q_{s-d}=0.003$, said the ambient temperature is maintained unchanged conditions, the daily average heat accumulation for each additional $1 \mathrm{MJ}$ relative to the daily average heat collection efficiency increased 0.003; partial regression coefficient $T_{3}=0.007$ that the daily average heat accumulation is maintained unchanged conditions, the ambient temperature for

Table 4. Experimental data processing results.

\begin{tabular}{ccccc}
\hline R Square & Standard deviation & Significance $F$ & $T_{3}$ & $Q_{s-d}$ \\
\hline 0.957 & 0.024 & 0.018 & 0.007 & 0.003 \\
\hline
\end{tabular}


each additional $1^{\circ} \mathrm{C}$, relative to the daily average heat collection efficiency increased $0.007 \mathrm{~m}^{3}$.

\section{Results and Discussion}

\subsection{Economic Benefits Analysis}

\subsubsection{Installation Fee}

See Table 5.

\subsubsection{Raw Material Cost}

Assuming that the fermenting raw materials and the output of the biogas slurry sludge benefit is quite, can be ignored.

\subsubsection{Maintenance and Management Costs}

Solar photovoltaic power generation system, three-year battery warranty, solar components warranty for ten years, inverter, controller and other parts warranty for one year. In the course of not violating the operating system can be used normally for 15 years, during storage, the natural attenuation of consumables such as inverters require maintenance.

The management fee for the biogas fermentation system includes the annual out-of-the-art labor costs and the biennial maintenance costs, maintenance costs, including maintenance of materials in the system, spare parts costs.

\subsubsection{Operating Cost}

Solar energy is clean energy inexhaustible, biomass energy as the fermentation raw material is waste recycling for the user. Water within the system can be recycled, closed pipe water consumption is minimal, basically the same. Table 6 shows the cost of production inputs.

\subsection{Output Performance}

\subsubsection{Biogas}

The experimental results show that when the system is running stably, $1.50 \mathrm{~m}^{3}$ per day biogas production. In the system, the burning efficiency of coal-fired stoves is $60 \%$, the burning efficiency of biogas stoves is $75 \%$, the average calorific value of biogas is $22.94 \mathrm{MJ} / \mathrm{m}^{3}$, the calorific value of standard coal is $29.30 \mathrm{MJ} / \mathrm{kg}$ [9], the standard coal price is 1.50 yuan $/ \mathrm{kg}$ [15].

The value of biogas can calculate as below in Equation (14).

Table 5. System installation fee schedule.

\begin{tabular}{|c|c|c|}
\hline Device & Specifications Model & Cost \\
\hline Solar photovoltaic modules & $1000 \mathrm{~W}$ & 16,000 \\
\hline Vacuum tube solar collector components & $\begin{array}{l}\text { Vacuum collector tube } \varphi 58^{\star} 1800 \\
\text { Circulating pump CRS } 25-8\end{array}$ & 16,200 \\
\hline $\begin{array}{l}\text { Solar constant temperature biogas tank } \\
\text { components }\end{array}$ & Vacuum collector tube $\varphi 58^{\star} 1800$ & 9200 \\
\hline total & & 41,400 \\
\hline
\end{tabular}


Table 6. Cost of production inputs.

\begin{tabular}{cccc}
\hline $\begin{array}{c}\text { System to increase the } \\
\text { cost of fees }\end{array}$ & $\begin{array}{c}\text { Solar constant temperature } \\
\text { biogas digester fermentation } \\
\text { raw materials costs }\end{array}$ & $\begin{array}{c}\text { Maintenance, } \\
\text { management and } \\
\text { operating costs }\end{array}$ & $\begin{array}{c}\text { Total } \\
\text { Investment } \\
\text { Costs }\end{array}$ \\
\hline $41,400.00$ yuan & $\begin{array}{c}\text { And biogas fertilizer income } \\
\text { offset }\end{array}$ & 100.00 yuan & $41,500.00$ yuan \\
\hline$T_{1}=\frac{C_{1} \times E_{1}}{C_{2} \times E_{2}} \times T_{2}$ &
\end{tabular}

where in, $C_{1}$-Calorific value of biogas;

$E_{1}$-Combustion efficiency of biogas;

$C_{2}$-Calorific value of the alternative fuel;

$E_{2}$-Alternative fuel combustion efficiency;

$T_{1}$-Value of biogas;

$T_{2}$-Price of alternative fuels.

Calculated the value of biogas is 1.50 yuan $/ \mathrm{m}^{3}$.

\subsubsection{Living Hot Water}

The experimental study shows that the system is stable throughout the year to provide households with continuous hot water, the average consumption of hot water is $\mathrm{Q}_{\mathrm{w}}=33.18 \mathrm{~kJ} / \mathrm{d}$, the calorific value of standard coal is $29.30 \mathrm{MJ} / \mathrm{kg}$, by considering the traditional way using coal to provide hot water of calculation of the annual consumption of hot water of standard coal $413.33 \mathrm{~kg}$.

\subsubsection{Winter Heating}

According to the heat transfer formula, the heating energy consumption of traditional rural buildings in winter is $279.77 \mathrm{MJ} / \mathrm{d}$, during the experiment period; $680.70 \mathrm{~kg}$ of standard coal was consumed. According to the investigation of the building area, traditional farm houses, including winter heating, the average annual use of about $6500.00 \mathrm{~kg}$ of standard coal. Compared with the traditional way of supply, the system is equivalent to annual savings of $5819.30 \mathrm{~kg}$ of standard coal heating.

\subsubsection{Electricity}

During the experiment period, the total generating capacity was $231.37 \mathrm{kWh}$, the average daily generating capacity was $2.49 \mathrm{kWh}$ and the total electricity consumption was $124.27 \mathrm{kWh}$. Thus, the system produces more energy by 107.10 $\mathrm{kWh}$, providing electricity more than the user demands. Farmers consume about $3.00 \mathrm{kWh}$ of electricity a day, a total of about $1277.50 \mathrm{kWh}$ a year; in accordance with the power of the standard coal conversion coefficient $0.41 \mathrm{~kg} / \mathrm{kWh}$ calculation, compared with the traditional use of electricity in the family, the annual savings of $385.00 \mathrm{~kg}$ of standard coal.

The system can be stable during the winter season for households to provide continuous hot water, biogas, and to meet heating needs. 


\subsubsection{Environmental Benefits}

The cumulative cost is $42,503.76$ yuan, the cumulative benefits value is $110,877.13$ yuan, the benefit cost ratio is 2.61 , the investment recovery period is 4.37 years, the net present value is $68,373.37$ yuan, and the internal rate of return is $25.50 \%$. Compared with the traditional rural energy supply system, the rural green building annual savings of coal is $7364.13 \mathrm{~kg}$ per kilogram of standard coal emissions of carbon dioxide $3.67 \mathrm{~kg}, 27.03$ tons of carbon dioxide emissions.

Daily life cooking is no longer subject to smoke, reduce labor intensity, the liberation of women labor, manure into the pool fermentation, reduce disease transmission rate, improve the rural health level; the same time, efficient use of clean energy to help farmers From the traditional way of life to a healthy, civilized, healthy lifestyle change, the construction of new rural areas had a positive impact.

To improve the rural living environment and ecological environment, and promote the pace of urbanization in rural areas to ease the contradiction between rural living energy and industrial energy, while achieving energy saving.

\section{Acknowledgements}

I would like to express my gratitude to all those who helped me during the writing of this paper. I gratefully acknowledge the help of my supervisor, Mr. Li Jinping, who has offered me valuable suggestions in the academic studies. In the preparation of the paper, he has spent much time reading through each draft and provided me with inspiring advice. Without his patient instruction, insightful criticism and expert guidance, the completion of this paper would not have been possible. I should finally like to express my gratitude to my beloved parents who have always been helping me out of difficulties and supporting without a word of complaint. This work was supported by the national high technology research and development program of China (2014AA052801).

\section{References}

[1] Shukla, R., Sumathy, K. and Erickson, P. (2013) Recent Advances in the Solar Water Heating Systems: A Review. Renewable and Sustainable Energy Reviews, 19, 173-190. https://doi.org/10.1016/j.rser.2012.10.048

[2] China Solar Water Heater Market Depth Survey Analysis and Development Trend of the Report (2016-2020) http://www.cir.cn

[3] Rahman, M.M., Hasan, M.M. and Paatero, J.V. (2014) Hybrid Application of Biogas and Solar Resources to Fulfill Household Energy Needs: A Potentially Viable Option in Rural Areas of Developing Countries. Renewable Energy, 68, 35-45. https://doi.org/10.1016/j.renene.2014.01.030

[4] Nakata, T., Kubo, K. and Lamont, A. (2005) Design for Renewable Energy Systems with Application to Rural Areas in Japan. Energy Policy, 33, 209-219. https://doi.org/10.1016/S0301-4215(03)00218-0

[5] Dagdougui, H., Minciardi, R. and Ouammi, A. (2012) Modeling and Optimization of a Hybrid System for the Energy Supply of a "Green" Building. Energy Conversion and Management, 64, 351-363. 
https://doi.org/10.1016/j.enconman.2012.05.017

[6] Gaul, M. (2013) A Comparative Study of Small-Scale Rural Energy Service Pathways for Radiationing, Cooking and Mechanical Power. Applied Energy, 101, 376-392. https://doi.org/10.1016/j.apenergy.2012.03.050

[7] Helal, A., Ghoneim, W. and Halaby, A. (2013) Feasibility Study for Self-Sustained Wastewater Treatment Plants-Using Biogas CHP Fuel Cell, Micro-Turbine, PV and Wind Turbine Systems. Smart Grid and Renewable Energy, 4, 227-235. https://doi.org/10.4236/sgre.2013.42028

[8] Jenssen, T., König, A. and Eltrop, L. (2014) Bioenergy Villages in Germany: Bringing a Low Carbon Energy Supply for Rural Areas into Practice. Renewable Energy, 61, 74-80. https://doi.org/10.1016/j.renene.2012.08.014

[9] González-González, A., Collares-Pereira, M. and Cuadros, F. (2014) Energy Self-Sufficiency through Hybridization of Biogas and Photovoltaic Solar Energy: An Application for an Iberian Pig Slaughterhouse. Journal of Cleaner Production, 65, 318-323. https://doi.org/10.1016/j.jclepro.2013.08.021

[10] Hosseinalizadeh, R., Shakouri, H., Amalnick, M.S. and Taghipour, P. (2016) Economic Sizing of a Hybrid (PV-WT-FC) Renewable Energy System (HRES) for Stand-Alone Usages by an Optimization-Simulation Model: Case Study of Iran. Renewable and Sustainable Energy Reviews, 54, 139-150.

[11] Chauhan, A. and Saini, R.P. (2016) Techno-Economic Feasibility Study on Integrated Renewable Energy System for an Isolated Community of India. Renewable and Sustainable Energy Reviews, 59, 388-405.

https://doi.org/10.1016/j.rser.2015.12.290

[12] Tian, Y.S. (2011) Status of China's Rural Energy Development and Prospects for the Twelfth Five-Year Plan. China Energy, 33, 13-16.

[13] Zhang, L.H. and Cao, X.C. (2012) A System Dynamics Study of the Development of Rural Energy in Shandong Province. International Conference on Civil Engineering and Urban Planning 2012, Yantai, 18-20 August 2012, 20-22. https://doi.org/10.1061/9780784412435.012

[14] Kaygusuz, K. (2011) Energy Services and Energy Poverty for Sustainable Rural Development. Renewable and Sustainable Energy Reviews, 15, 936-947. https://doi.org/10.1016/j.rser.2010.11.003

[15] Bai, J.H. (2011) Solar Heating Thermostatic Biogas Digester Gas Performance Experimental Research. Mater Dissertation, Lanzhou University of Technology, Lanzhou.

[16] Christiaensen, L. and Heltberg, R. (2014) Greening China's Rural Energy: New Insights on the Potential of Smallholder Biogas. Environment \& Development Economics, 19, 8-29. https://doi.org/10.1017/S1355770X13000375

[17] Shanghai Urban Construction and Communications Commission (2010) GB 50015-2003 Code for Water Supply and Drainage of Buildings. China Planning Press, Beijing.

[18] Ministry of Housing and Urban and Rural Development (MOHURD) (2010) JGJ26-2010 Design Standard for Energy Efficiency of Residential Buildings in Cold and Cold Areas. China Architecture and Building Press, Beijing.

[19] Zhao, G., Ma, F. and Wei, L. (2011) Research and Prospect of Northern Low Temperature Biogas Fermentation Technology. Harbin Institute of Technology, 6, 29-33.

[20] Li, J.-P., Ma, S.C. and Diao, R.D. (2012) The New Rural Construction of Green 
Building and Energy Consumption Analysis. China Biogas, 30, 28-32.

[21] Wang, X.C., He, G.X. and Qiu, L. (2008) The Solar Heat Pipe Heating System in the Application of Biogas Engineering. Journal of Agricultural Mechanization Research, 7, 204-207.

[22] Fu, X.Q., Chen, Z.A. and Deng, L.W. (2002) Large-Scale Pig Waste Treatment Pool Capacity. China Biogas, 20, 24-27.

[23] Huang, P.C., Chen, C.C. and Hwang, H.Y. (2013) Thermal Enhancement in a Flat-Plate Solar Water Collector by Flow Pulsation and Metal-Foam Blocks. International Journal of Heat and Mass Transfer, 61, 696-720. https://doi.org/10.1016/j.ijheatmasstransfer.2013.02.037

[24] Yan, X., Ohara, T. and Akimoto, H. (2006) Bottom-Up Estimate of Biomass Burning in Mainland China. Atmospheric Environment, 40, 5262-5273. https://doi.org/10.1016/j.atmosenv.2006.04.040

[25] Tonooka, Y., Liu, J. and Kondou, Y. (2006) A Survey on Energy Consumption in Rural Households in the Fringes of Xi'an City. Energy and Buildings, 38, 1335-1342. https://doi.org/10.1016/j.enbuild.2006.04.011

[26] Chen, L., Heerink, N. and van den Berg, M. (2006) Energy Consumption in Rural China: A Household Model for Three Villages in Jiangxi Province. Ecological Economics, 58, 407-420. https://doi.org/10.1016/j.ecolecon.2005.07.018

[27] Yao, C., Chen, C. And Li, M. (2012) Analysis of Rural Residential Energy Consumption and Corresponding Carbon Emissions in China. Energy Policy, 41, 445-450. https://doi.org/10.1016/j.enpol.2011.11.005

[28] Ministry of Housing and Urban-Rural Development of China (2012) GB/T50824-2013 Design Standard of Energy Efficiency of Rural Residential Buildings. China Architecture and Building Press, Beijing.

[29] China Academy of Building Research (2012) GB 50736-2012 Code for Design of Heating Ventilation and Air Conditioning in Civil Buildings. China Architecture and Building Press, Beijing.

[30] Gao, H.T. (2012) The Performance of the Wind-Solar Power-Biogas Integrated System Research. Lanzhou University of Technology, Lanzhou. 